\title{
Front Matter: Volume 11679
}

, "Front Matter: Volume 11679," Proc. SPIE 11679, High-Power Laser Materials Processing: Applications, Diagnostics, and Systems X, 1167901 (20 April 2021); doi: 10.1117/12.2596563 


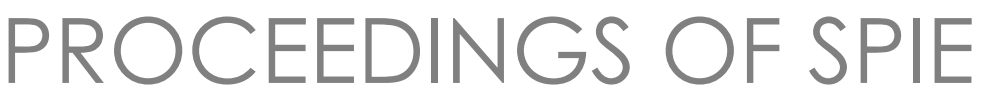

\title{
High-Power Laser Materials Processing: Applications, Diagnostics, and Systems $X$
}

\author{
Stefan Kaierle \\ Stefan W. Heinemann
}

Editors

6-11 March 2021

Online Only, United States

Sponsored and Published by

SPIE 
The papers in this volume were part of the technical conference cited on the cover and title page. Papers were selected and subject to review by the editors and conference program committee. Some conference presentations may not be available for publication. Additional papers and presentation recordings may be available online in the SPIE Digital Library at SPIEDigitalLibrary.org.

The papers reflect the work and thoughts of the authors and are published herein as submitted. The publisher is not responsible for the validity of the information or for any outcomes resulting from reliance thereon.

Please use the following format to cite material from these proceedings:

Author(s), "Title of Paper," in High-Power Laser Materials Processing: Applications, Diagnostics, and Systems X, edited by Stefan Kaierle, Stefan W. Heinemann, Proceedings of SPIE Vol. 11679 (SPIE, Bellingham, WA, 2021) Seven-digit Article CID Number.

ISSN: 0277-786X

ISSN: 1996-756X (electronic)

ISBN: 9781510641938

ISBN: 9781510641945 (electronic)

Published by

SPIE

P.O. Box 10, Bellingham, Washington 98227-0010 USA

Telephone +1 3606763290 (Pacific Time) · Fax +1 3606471445

SPIE.org

Copyright (c) 2021, Society of Photo-Optical Instrumentation Engineers.

Copying of material in this book for internal or personal use, or for the internal or personal use of specific clients, beyond the fair use provisions granted by the U.S. Copyright Law is authorized by SPIE subject to payment of copying fees. The Transactional Reporting Service base fee for this volume is $\$ 21.00$ per article (or portion thereof), which should be paid directly to the Copyright Clearance Center (CCC), 222 Rosewood Drive, Danvers, MA 01923. Payment may also be made electronically through CCC Online at copyright.com. Other copying for republication, resale, advertising or promotion, or any form of systematic or multiple reproduction of any material in this book is prohibited except with permission in writing from the publisher. The CCC fee code is $0277-$ $786 \mathrm{X} / 21 / \$ 21.00$.

Printed in the United States of America by Curran Associates, Inc., under license from SPIE.

Publication of record for individual papers is online in the SPIE Digital Library.

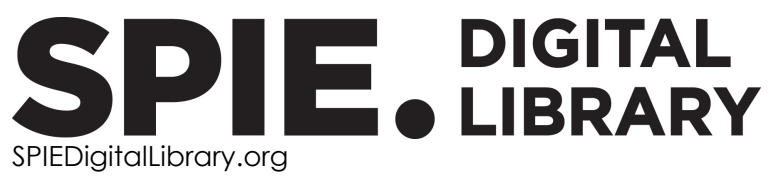

Paper Numbering: Proceedings of SPIE follow an e-First publication model. A unique citation identifier (CID) number is assigned to each article at the time of publication. Utilization of CIDs allows articles to be fully citable as soon as they are published online, and connects the same identifier to all online and print versions of the publication. SPIE uses a seven-digit CID article numbering system structured as follows:

- The first five digits correspond to the SPIE volume number.

- The last two digits indicate publication order within the volume using a Base 36 numbering system employing both numerals and letters. These two-number sets start with $00,01,02,03,04$, 05, 06, 07, 08, 09, OA, OB ... 0Z, followed by 10-1Z, 20-2Z, etc. The CID Number appears on each page of the manuscript. 


\section{Contents}

PROCESS CONTROL

1167908 Depth monitoring system during laser processing using KTN-based wavelength-swept light source of 1.3- $\mu \mathrm{m}$ wavelength band [1 1679-5]

WELDING

1167909 Laser beam welding with mobile vacuum: MoVac [1 1679-6]

CUTTING AND DRILLING

11679 OC Cutting and drilling of CFRP by using 3-kW CW single-mode fiber laser and galvanometer scanner [1 1679-9]

11679 OE Development of an on-the-fly percussion drilling process based on pulse bursts [11679-11]

\section{SURFACE TREATMENT}

$11679 \mathrm{OH} \quad$ Development of high-power laser ablation process for polycrystalline diamond polishing: part 3. processing with an ultra-short-pulsed laser up to $1 \mathrm{~kW}$ [11679-14]

$11679 \mathrm{OJ} \quad$ Application of nanoindentation technique to test surface hardness and residual stress of NiTi alloy after femtosecond laser shock peening [11679-20]

\section{OPTICAL SYSTEMS}

$11679 \mathrm{OL} \quad$ Thermal lensing mitigation for high power laser processing [11679-17] 
Proc. of SPIE Vol. 11679 1167901-4

\section{Downloaded From: https://www.spiedigitallibrary.org/conference-proceedings-of-spie on 26 Apr 2023
Terms of Use: https://www.spiedigitallibrary.org/terms-of-use}

